\title{
The nutritive value of bread protein as influenced by the level of protein intake, the level of supplementation with L-lysine and $L$-threonine, and the addition of egg and milk proteins
}

\author{
By J. B. HUTCHINSON, T. MORAN AND J. PACE \\ Research Association of British Flour-Millers, Cereals Research Station, \\ Old London Road, St Albans
}

(Received I August 1958-Revised 12 November 1958)

Over 40 years ago Osborne \& Mendel (I914) showed that the protein of wheat is deficient in lysine. This limitation of the nutritive value of wheat protein was emphasized when Rose's (1937) classical work established that the requirement for lysine of the weanling rat is higher than for any of the other indispensable amino acids.

If the amino-acid composition of wheat and flour proteins is considered together with Rose's data on the minimum levels of the essential amino acids required for optimum growth (Rose, Smith, Womack \& Shane, 1949), it is now apparent not only that lysine is the amino acid primarily limiting the nutritive value of the protein, but also that the content of the amino acids is such that the nutritive value of the protein may be substantially improved by a small addition of lysine.

In recent years this presumption from the data of the protein chemist has been amply confirmed in investigations on the growth of rats, by Rosenberg \& Rohdenburg (1952), Sure (1953), Hutchinson, Moran \& Pace (1956b) and Deshpande, Harper \& Elvehjem (1957); on net protein utilization in the rat by Bender (I957); on nitrogen balance in dogs by Allison (1949); and on human adults in a state of protein depletion by Hoffman \& McNeil (I949).

With this general agreement, that it is lysine that primarily limits the nutritive value of wheat protein, firmly established, several investigators have subsequently examined the effect of supplementing wheat protein with other amino acids in addition to lysine. Some of the results obtained have been apparently contradictory. For example, Sure (1953) and Hundley, Ing \& Krauss (1956) found a supplement of lysine with threonine better than one of lysine alone, whereas Rosenberg, Rohdenburg \& Baldini (1954) found no additional effect with threonine, valine or methionine and, as Bender (1958) has pointed out, there has been some confusion in interpreting the results.

In our opinion the discrepancies in the results recorded in the literature when the rat-growth method has been used have arisen primarily because different investigators have used different levels of protein in the diet and have frequently studied the effect of supplementation at only one level of protein. Furthermore, in some of the work an amino acid has been added only at one level which sometimes has been excessively high. For these reasons the interrelated aspects of protein level and food consumption, particularly important with an unbalanced protein, and the possible effect of the level of addition of the amino acid upon palatability and appetite have not 
usually been clarified. The importance of information on the effect of such dietary conditions for the interpretation of data on the supplementation of plant proteins by amino acids has been stressed in a recent review by Waddell (1958).

In the experiments described below the influence of these factors has been investigated with white bread as the source of protein. Measurements of the growth of weanling rats have been made with different levels of bread protein in the diet and with different levels of supplementation with amino acids. Food consumption has been measured in all experiments to examine any effect on palatability and appetite.

\section{EXPERIMENTAL AND RESULTS}

\section{Materials}

Flour. All the flour was milled in the laboratory from clean wheat. The extraction rate of the flour from the wheat was about $67 \%$. For the diets in which bread supplied about $2.2 \%$ nitrogen the flour was milled from Manitoba wheat. For the diets of lower protein content the flour was milled from mixed grists of selected English wheats of low protein content.

'High-protein' flours. These were prepared by our colleague, Dr C. R. Jones, from flours of normal protein content by using the technique of air classification (Jones, Halton \& Stevens, 1959). By these methods it was possible to prepare flours with protein contents as high as $26 \%$.

Bread. Bread was made in the laboratory with $15 \mathrm{~g}$ yeast $/ 800 \mathrm{~g}$ flour; no salt was included in the dough. After baking, the loaves were sliced. The slices were dried on trays in a cabinet with circulating air at a temperature of $57-60^{\circ}$ and powdered in a hammer mill. The resulting material was used in the diets. Nitrogen and moisture determinations were made on each batch of dried bread.

Whole-egg protein. The yolks and whites of fresh eggs were thoroughly mixed together and then extracted at room temperature with successive volumes of acetone. The residue was filtered at the pump, extracted with several volumes of diethyl ether, air-dried and then analysed for nitrogen, moisture, fat and ash. It had the following composition on a dry-weight basis: nitrogen ${ }^{3} 3^{\cdot 25}$, fat 8.88 and ash $4.38 \%$.

Casein. 'Low Vitamin Content' Casein (Genatosan Ltd, Loughborough) was used.

Milk powder. Spray-dried skim-milk powder (Fison's Milk Products Ltd) was used.

\section{Diets}

The composition of the diets is given in Table $\mathbf{I}$.

\section{Animals and their management}

Male weanling piebald rats from our own colony were used. Each rat was kept in a separate cage with a perforated false bottom. The room temperature was maintained at $70^{\circ} \mathrm{F}$. Food and water were supplied ad lib. Food consumption was measured daily and each rat was weighed twice a week. Usually the growth rate was measured over a period of 28 days from weaning. In some instances, when supplies of a dietary ingredient were limited, the period of measurement was less than 28 days; these 
Vol. I3

岁

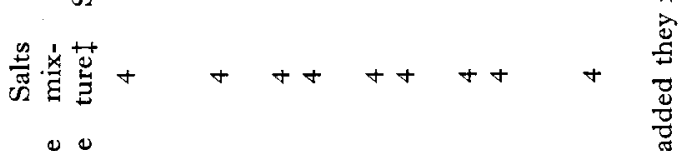

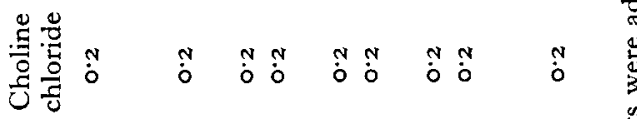

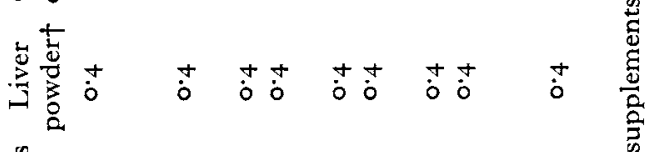

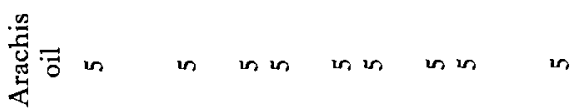

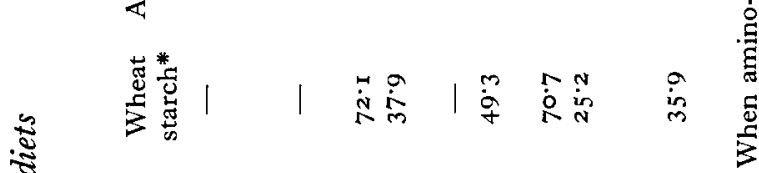

$\dot{\vec{q}}$

:

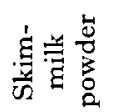

总

$+\dot{0}$

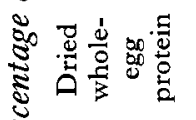

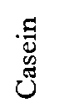

$+$

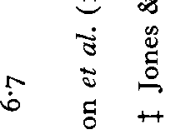

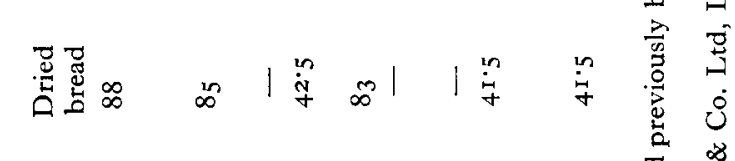

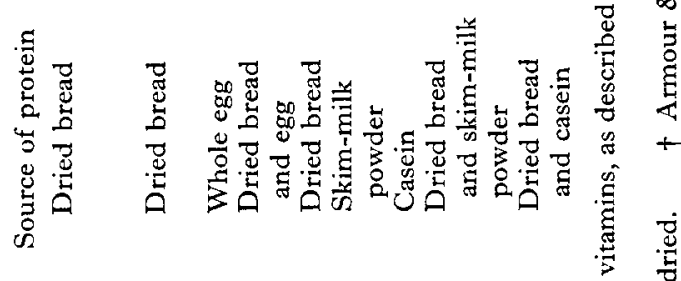

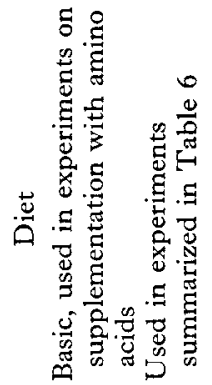

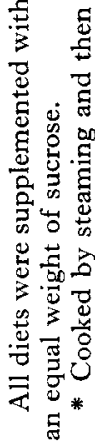


shorter experiments are noted in Tables 4,5 and 6 . We have, however, invariably found in this work that the comparative results with different treatments obtained $7^{-1} 4$ days from weaning were similar to those after $2 \mathbf{I}-28$ days.

\section{Methods}

Analytical. Nitrogen determinations were made by the Kjeldahl or micro-Kjeldahl method. Amino acids were determined on hydrolysates of flour, bread and egg protein by ion-exchange chromatography by the methods of Moore \& Stein (I95I) with the operating conditions given by McDermott \& Pace (1957).

Statistical. The experiments were designed as randomized blocks of litter-mates. In many experiments the litters were large enough to accommodate more than one replicate of the treatments; in one experiment, presented in Table 3 , the litters were not large enough for one replicate, and a balanced incomplete block design was used. The number of rats per treatment and the number of degrees of freedom for error for each experiment are given in the tables.

\section{Amino-acid composition of 'high-protein' flour}

The development of methods of producing 'high-protein' flours has made possible investigation of the nutritive value of the protein of bread at levels hitherto unattainable. (The protein values of flour and bread given in this paper were calculated by multiplying the nitrogen content by $5 \cdot 7$, the conventional factor for cereal protein.) Before the feeding trials determinations of the amino-acid composition of this derived flour of high protein content were made to check whether the process of concentration had affected the composition of the protein by, for example, preferentially segregating certain fractions of the complex protein system of the endosperm of the wheat grain. The results for a flour of $26.8 \%$ protein are given in Table 2, together with those for the parent flour (from a grist of English wheat) from which it was derived and, for comparison, the values previously reported by McDermott $\&$ Pace (1957) for a typical baking flour milled from a mixed grist.

It will be seen that the concentration process does not substantially change the amino-acid composition of the protein. Minor changes in the content of certain amino acids occur, but these are no greater than the small differences between the composition of the protein of the parent flour and that of the flour from a mixed grist.

\section{Rate of growth of weanling rats at high levels of bread protein, alone and supplemented with L-lysine}

Previous work by Hutchinson et al. (1956b) showed that with diets containing about $12-13 \%$ bread protein the growth rate of weanling rats is approximately trebled when $0.2-0.3 \%$ L-lysine is added to the diets. As high-protein flours became available it was possible for the first time to study the effect upon growth of bread proteins beyond the $13 \%$ level and also to examine whether there was still a response to added lysine at the higher levels of protein. Measurements of growth rate and food consumption were made at protein levels of $10.8,15 \cdot 0,18.8$ and $24.6 \%$ with and without the 
addition of L-lysine, and the results are given in Table 3. The amount of L-lysine added to the diets was $0.4 \%$.

There was a substantial response to added lysine at all levels of bread protein. Thus lysine continued to be the limiting amino acid up to and including the $24.6 \%$ protein level. Although the rate of growth was high, $5 \mathrm{~g} /$ day, at this protein level with the lysine supplement, the protein efficiency ratio was less than with the supplemented diet containing $10.8 \%$ protein. This latter diet gave a higher protein efficiency ratio than the unsupplemented diet of $24.6 \%$ protein content but the rate of gain in weight was similar on the two.

Table 2. Content of amino acids in hydrolysates of flour of high and of average protein content

\begin{tabular}{|c|c|c|c|}
\hline \multirow[b]{2}{*}{ Amino acid } & \multicolumn{3}{|c|}{ Amino-acid nitrogen (g/100 $\mathrm{g}$ total $\mathrm{N})$} \\
\hline & $\begin{array}{c}\text { Parent flour } \\
\text { (1 } 1 \cdot 30 \% \text { protein } t)\end{array}$ & $\begin{array}{c}\text { Derived high- } \\
\text { protein flour } \\
(26.8 \% \text { protein } \dagger)\end{array}$ & $\begin{array}{c}\text { A typical } \\
\text { baking flour* } \\
(12.9 \% \text { protein } \dagger)\end{array}$ \\
\hline Alanine & $2 \cdot 70$ & $2 \cdot 87$ & $2 \cdot 87$ \\
\hline Arginine & 一 & 一 & $6 \cdot 72$ \\
\hline Aspartic acid & $2 \cdot 80$ & $2 \cdot 60$ & $2 \cdot 66$ \\
\hline Cystine & $x \cdot 65$ & - & $x \cdot 68$ \\
\hline Glutamic acid & $18 \cdot 66$ & 19.69 & $19 \cdot 94$ \\
\hline Glycine & $3 \cdot 84$ & - & 3.93 \\
\hline Histidine & $3 \cdot 26$ & $3 \cdot 66$ & 3.59 \\
\hline Isoleucine & $2 \cdot 57$ & $2 \cdot 56$ & $2 \cdot 55$ \\
\hline Leucine & $4 \cdot 72$ & $4 \cdot 76$ & $4 \cdot 8 \mathrm{I}$ \\
\hline Lysine & $2 \cdot 30$ & $2 \cdot 38$ & $2 \cdot 36$ \\
\hline Methionine & 0.98 & 0.98 & $1 \cdot 05$ \\
\hline Phenylalanine & $2 \cdot 61$ & $2 \cdot 75$ & 2.80 \\
\hline Proline & $8 \cdot 30$ & $8 \cdot 75$ & $8 \cdot 83$ \\
\hline Serine & 3.90 & 4.08 & 3.89 \\
\hline Threonine & $1 \cdot 98$ & 2.07 & 2.05 \\
\hline Tryptophan & - & - & 0.98 \\
\hline Tyrosine & $I \cdot 4 I$ & $I \cdot 46$ & $I \cdot 6 I$ \\
\hline Valine & $3 \cdot 18$ & $3 \cdot 13$ & $3 \cdot 28$ \\
\hline
\end{tabular}

Table 3. Rate of growth of weanling rats over 28 days on diets containing 10.8, $15.0,18.8$ and $24.6 \%$ bread protein alone or supplemented with $0.4 \%$ L-lysine

\begin{tabular}{|c|c|}
\hline \multicolumn{2}{|c|}{ Diet } \\
\hline $\begin{array}{c}\text { Bread } \\
\text { protein } \\
(\%)\end{array}$ & $\begin{array}{c}\text { Nitrogen } \\
(\%)\end{array}$ \\
\hline \multirow[t]{2}{*}{10.8} & $\mathrm{I} \cdot 89$ \\
\hline & $I^{\circ} 97$ \\
\hline \multirow[t]{2}{*}{15.0} & $2 \cdot 63$ \\
\hline & $2 \cdot 70$ \\
\hline \multirow[t]{2}{*}{18.8} & $3 \cdot 30$ \\
\hline & $3 \cdot 3^{6}$ \\
\hline \multirow[t]{2}{*}{$24 \cdot 6$} & $4 \cdot 31$ \\
\hline & $4 \cdot 39$ \\
\hline
\end{tabular}

(Seven rats/treatment)

Standard

L-lysine
added $(\%)$
None
0.4
None
0.4
None
0.4
None
0.4

Weight gain
(g/rat/day)
$1 \cdot 0$
$3 \cdot 0$
$\mathbf{1} \cdot 6$
4.75
$\mathbf{1} \cdot 6$
4.75
2.7
5.05
\pm 0.12

Food
consumption
(g/rat/day)
$7 \cdot 25$
10.15
$8 \cdot 0$
$12 \cdot 1$
8.3
11.8
9.6
12.2
\pm 0.25

Weight gain (g) per $\mathrm{g} \mathrm{N}$ consumed 
Effect of adding other amino acids to bread protein, supplemented with $L_{L}$-lysine at protein levels of $12 \cdot 7-13 \cdot 0 \%$ and $7 \cdot 6-7 \cdot 8 \%$

The effect of level of protein was investigated, and the results are given in Table 4. L-Lysine was added at the level of $0.25 \%$ of the diet, shown in previous work by Hutchinson $e t$ al. (1956b) to be sufficient to produce maximum growth rate with bread protein at the $12-13 \%$ level. Both DL-threonine and L-threonine were used since some investigators have used the racemic form. In some experiments methionine and tryptophan were also added. Bender (1958) found an additional effect with methionine in his work on net protein utilization.

Table 4. Effect of addition of threonine and methionine to bread protein supplemented with L-lysine $(0.25 \%$ of the diet) on rate of growth of weanling rats over 28 days

(Eight rats/treatment except in the experiment with $7.6 \%$ protein when there were six)

\begin{tabular}{|c|c|c|c|c|c|}
\hline $\begin{array}{l}\text { Protein } \\
\text { content of } \\
\text { diet }(\%)\end{array}$ & $\begin{array}{l}\text { Other amino acids } \\
\text { added } \\
\text { (percentage of diet) }\end{array}$ & $\begin{array}{l}\text { Nitrogen } \\
\text { content of } \\
\text { supple- } \\
\text { mented } \\
\text { diet }(\%)\end{array}$ & $\begin{array}{c}\text { Mean } \\
\text { weight } \\
\text { gain } \\
\text { (g/rat/day) }\end{array}$ & $\begin{array}{c}\text { Mean } \\
\text { food } \\
\text { intake } \\
\text { (g/rat } / \text { day })\end{array}$ & $\begin{array}{l}\text { Weight } \\
\text { gain }(\mathrm{g}) \\
\text { per } \mathrm{g} \mathrm{N} \\
\text { consumed }\end{array}$ \\
\hline 13.0 & None & $2 \cdot 28$ & $3 \cdot 2$ & 10.2 & I3. 8 \\
\hline (flour milled from & 0.1 DL-threonine & $2 \cdot 29$ & $3 \cdot 3$ & 10.45 & 13.9 \\
\hline \multirow[t]{3}{*}{ Manitoba wheat) } & 0.2 DL-threonine & $2 \cdot 3 I$ & $3 \cdot 3$ & 10.5 & $13 \cdot 6$ \\
\hline & 0.4 DL-threonine & $2 \cdot 32$ & $3 \cdot 35$ & 10.4 & I3.9 \\
\hline & $\begin{array}{l}0.2 \text { DL-threonine } \\
+0.15 \text { DL-methionine }\end{array}$ & $2 \cdot 3 I$ & 34 & 10.9 & I $3 \cdot 4$ \\
\hline $\begin{array}{l}\text { Standard error of } \\
\text { the mean }(28 \text { d.f. })\end{array}$ & & & \pm 0.11 & \pm 0.27 & \\
\hline I $2 \cdot 8$ & None & $2 \cdot 25$ & $3 \cdot 55$ & 10.7 & 14.8 \\
\hline (flour milled from & 0.1 L-threonine & $2 \cdot 26$ & 3.50 & $10 \cdot 6$ & 14.7 \\
\hline Manitoba wheat) & $\begin{array}{l}0.1 \text { L-threonine } \\
+0.15 \text { DL-methionine }\end{array}$ & $2 \cdot 28$ & $3 \cdot 65$ & $10 \cdot 9$ & $14 \cdot 8$ \\
\hline \multicolumn{2}{|c|}{$\begin{array}{l}\text { Standard error of } \\
\text { the mean ( } 18 \text { d.f.) }\end{array}$} & & \pm 0.08 & \pm 0.21 & \\
\hline \multirow{3}{*}{$\begin{array}{l}\text { I2.7 } \\
\text { (flour milled from } \\
\text { Manitoba wheat) }\end{array}$} & None & $2 \cdot 23$ & $3 \cdot 8$ & II 7 & I 4.5 \\
\hline & $\begin{array}{l}0.2 \text { DL-threonine } \\
+0.15 \text { DL-methionine }\end{array}$ & $2 \cdot 27$ & $3 \cdot 85$ & I $1 \cdot 7$ & $14 \%$ \\
\hline & $\begin{array}{l}0.2 \text { DL-threonine } \\
+0.15 \text { DL-methionine } \\
+0.1 \text { L-tryptophan }\end{array}$ & $2 \cdot 29$ & $3 \cdot 7$ & II $\cdot 8$ & I $3 \cdot 8$ \\
\hline \multicolumn{2}{|c|}{$\begin{array}{l}\text { Standard error of } \\
\text { the mean ( } 8 \text { d.f.) }\end{array}$} & & \pm 0.10 & \pm 0.25 & \\
\hline \multirow{4}{*}{$\begin{array}{l}\qquad 7 \cdot 6 \\
\text { (flour milled from } \\
\text { weak English } \\
\text { wheat) }\end{array}$} & None & I 33 & $I \cdot 05$ & $6 \cdot 6$ & I I $\cdot 8$ \\
\hline & 0.2 DL-threonine & I.35 & $2 \cdot 7$ & $10 \cdot 1$ & $19 \cdot 8$ \\
\hline & $\begin{array}{l}0.2 \text { DL-threonine } \\
\text { +0.I } 5 \text { DL-methionine }\end{array}$ & $I \cdot 36$ & $2 \cdot 7$ & $10 \cdot x$ & $19 \cdot 6$ \\
\hline & $\begin{array}{l}0.2 \text { DL-threonine } \\
\text { +o.I5 DL-methionine } \\
\text { +o.I L-tryptophan }\end{array}$ & $I \cdot 38$ & $2 \cdot 6$ & 10.0 & $18 \cdot 9$ \\
\hline $\begin{array}{l}\text { Standard error of } \\
\text { the mean ( } 17 \text { d.f.) }\end{array}$ & & & \pm 0.08 & \pm 0.23 & \\
\hline $7 \cdot 8^{*}$ & None & $\mathrm{I} \cdot 37$ & $1 \cdot 7$ & $9 \cdot 2$ & $13 \cdot 3$ \\
\hline $\begin{array}{l}\text { (flour milled from } \\
\text { weak English wheat) }\end{array}$ & O. I L-threonine & $I \cdot 38$ & $3 \cdot 3$ & $11 \cdot 6$ & $20 \cdot 5$ \\
\hline $\begin{array}{l}\text { Standard error of } \\
\text { the mean (I I d.f.) }\end{array}$ & & & \pm 0.13 & \pm 0.27 & \\
\hline
\end{tabular}

* The duration of this experiment was 14 days from weaning. 
Table 4 shows that with a protein level of $13.0 \%$ and supplementation with sufficient L-lysine $(0.25 \%)$ to ensure optimum response with this amino acid there was no additional response when threonine was also added. On the other hand, with a protein level of $7.8 \%$ and supplementation with $0.25 \% \mathrm{~L}$-lysine, the addition of $0.1 \%$ L-threonine produced an increase in growth rate of about $90 \%$ and in the protein efficiency ratio of about $55 \%$. There was no significant additional response at either protein level when methionine and tryptophan were also added.

Table 5. Effect of addition of L-threonine to bread protein supplemented with $0.5 \%$ L-lysine or with $0.25 \%$ L-lysine

(Rate of growth of weanling rats (six/treatment) over $2 \mathrm{I}$ days)

\begin{tabular}{|c|c|c|c|c|c|}
\hline $\begin{array}{l}\text { Protein content } \\
\text { of diet }(\%)\end{array}$ & $\begin{array}{l}\text { Other amino acids } \\
\text { added } \\
\text { (percentage of diet) }\end{array}$ & $\begin{array}{l}N \text { content } \\
\text { of supple- } \\
\text { mented } \\
\text { diet }(\%)\end{array}$ & $\begin{array}{c}\text { Mean } \\
\text { weight } \\
\text { gain } \\
\text { (g/rat } / \text { day })\end{array}$ & $\begin{array}{c}\text { Mean } \\
\text { food } \\
\text { intake } \\
(\mathrm{g} / \text { rat } / \text { day })\end{array}$ & $\begin{array}{l}\text { Weight } \\
\text { gain (g) } \\
\text { per g N } \\
\text { consumed }\end{array}$ \\
\hline \multirow{2}{*}{$\begin{array}{l}12 \cdot 9 \\
\text { (flour milled from } \\
\text { Manitoba wheat) }\end{array}$} & $\left.\begin{array}{l}0.25 \text { L-lysine } \\
0.1 \text { L-threonine }\end{array}\right\}$ & $2 \cdot 26$ & $3 \cdot 6$ & I I 'O & 14.5 \\
\hline & $\left.\begin{array}{l}0.5 \text { L-lysine } \\
0.1 \text { L-threonine }\end{array}\right\}$ & $2 \cdot 30$ & $4 \cdot 6$ & I I.5 & $17 \cdot 3$ \\
\hline \multicolumn{2}{|c|}{$\begin{array}{l}\text { Standard error } \\
\text { of the mean }(8 \text { d.f. })\end{array}$} & & \pm 0.09 & \pm 0.19 & \\
\hline \multirow{2}{*}{$\begin{array}{l}13 \cdot 2 \\
\text { (flour milled from } \\
\text { Manitoba wheat) }\end{array}$} & $\left.\begin{array}{ll}0.5 & \text { L-lysine } \\
0.1 & \text { L-threonine }\end{array}\right\}$ & $2 \cdot 3 \mathrm{I}$ & $4 \cdot 25$ & I I 5 & $16 \cdot 0$ \\
\hline & $\left.\begin{array}{l}0.5 \text { L-lysine } \\
0.2 \text { L-threonine }\end{array}\right\}$ & $2 \cdot 34$ & $4 \cdot 5$ & II' 9 & $16 \cdot 2$ \\
\hline \multicolumn{2}{|c|}{$\begin{array}{l}\text { Standard error } \\
\text { of the mean ( } 9 \text { d.f.) }\end{array}$} & & \pm 0.06 & \pm 0.18 & \\
\hline $\begin{array}{l}\text { Io.० } \\
\text { (flour milled from }\end{array}$ & $\left.\begin{array}{l}0.25 \text { L-lysine } \\
0.1 \text { L-threonine }\end{array}\right\}$ & $I \cdot 75$ & $3 \cdot 15$ & II 3 & I 5.8 \\
\hline $\begin{array}{l}\text { medium English } \\
\text { wheat) }\end{array}$ & $\left.\begin{array}{l}0.5 \text { L-lysine } \\
0.1 \text { L-threonine }\end{array}\right\}$ & $1 \cdot 78$ & 4.0 & I $2 \cdot 0$ & $18 \cdot 6$ \\
\hline \multicolumn{2}{|c|}{$\begin{array}{l}\text { Standard error of } \\
\text { the mean }(8 \mathrm{~d} . f .)\end{array}$} & & \pm 0.10 & \pm 0.26 & \\
\hline
\end{tabular}

Previous work by Hutchinson et al. $(\mathrm{I} 956 a, b)$ showed that at the $12.5 \%$ protein level there was no further improvement in growth rate when the lysine supplement was increased beyond the $0.25 \%$ level. Some investigators, however, have added lysine at a higher level, which would have the effect of increasing the lysine : threonine ratio in the diet-possibly to a point where threonine became limiting even at the I $2.5 \%$ protein level. This possibility was investigated by supplementing diets containing different levels of bread protein ( $12 \cdot 9-13.2 \%$ and $10 \%$ with $0.5 \%$ L-lysine and adding L-threonine. The results given in Table 5 show that when the L-lysine supplement was increased to $0.5 \%$ there was a significant response to the addition of L-threonine.

\section{Growth rates on bread supplemented with lysine and threonine, on bread supplemented with protein from egg or from milk and on diets with protein from egg or from milk}

The comparatively high rates of growth, shown in Table 5, obtained with bread supplemented with $0.5 \% \mathrm{~L}$-lysine and $0 . \mathrm{I}-0.2 \% \mathrm{~L}$-threonine, suggested that it might usefully be compared with those found with proteins of established high nutritive 
value. This comparison was made in experiments with whole-egg protein, casein and skim-milk powder, with the diets given in Table $\mathrm{I}$. The protein content of these diets was similar, and in those where bread was supplemented with the high-quality protein about half the protein was supplied by the bread. The results are given in Table 6 .

In all feeding trials the covariance of weight gains and food intakes was examined. It was usually high with $r \sim 0.8-0.9$, and it was therefore possible to use a linear regression relationship between the weight gains and food intakes. This relationship was of service when an amino-acid supplement significantly increased the food consumption as well as the weight gain, when compared with the control group, in the very early stages of the experiment. By such analysis it was then found that the increase in rate of growth was not completely accounted for by the increased food consumption.

Table 6. Growth of rats on diets with bread supplemented with lysine and threonine; with bread supplemented with proteins from egg or milk; with protein from egg or milk

(Six rats/treatment)

\begin{tabular}{|c|c|c|c|c|}
\hline $\begin{array}{l}\text { Source of protein } \\
\text { in diet }\end{array}$ & $\begin{array}{l}\text { Nitrogen } \\
\text { content of } \\
\text { diet }(\%)\end{array}$ & $\begin{array}{c}\text { Mean weight } \\
\text { gain } \\
\text { (g/rat/day) }\end{array}$ & $\begin{array}{l}\text { Mean food } \\
\text { intake } \\
(\mathrm{g} / \mathrm{rat} / \text { day })\end{array}$ & $\begin{array}{l}\text { Weight gain }(\mathrm{g}) \\
\text { per } \mathrm{g} \mathrm{N} \\
\text { consumed }\end{array}$ \\
\hline $\begin{array}{l}\text { Bread }+0.5 \% \text { L-lysine } \\
\quad+0.2 \% \text { L-threonine }\end{array}$ & $2 \cdot 31$ & $4 \cdot 8$ & II.O & 18.8 \\
\hline Whole-egg protein & $2 \cdot 23$ & $5 \cdot 6$ & $10 \cdot 7$ & $23 \cdot 3$ \\
\hline Bread + whole-egg protein & $2 \cdot 16$ & $4 \cdot 2$ & 10.8 & $18 \cdot 1$ \\
\hline $\begin{array}{l}\text { Bread + whole-egg } \\
\text { protein }+0.2 \% \text { L-lysine } \\
\text { Standard error of the } \\
\text { mean ( } 5 \text { d.f.) }\end{array}$ & $2 \cdot 08$ & $\begin{array}{r}4.9 \\
+0.12\end{array}$ & $\begin{array}{l}10.9 \\
\pm 0.14\end{array}$ & $2 \mathrm{r} \cdot 7$ \\
\hline $\begin{array}{l}\text { Bread }+0.5 \% \text { L-lysine } \\
\quad+0.2 \% \text { L-threonine }\end{array}$ & $2 \cdot 29$ & $4 \cdot 5$ & II 6 & 16.8 \\
\hline Skim-milk powder & $2 \cdot 26$ & $3 \cdot 7$ & $10 \cdot 3$ & $15 \cdot 9$ \\
\hline Casein & $2 \cdot 25$ & $4 * 3$ & II $\cdot 3$ & 16.9 \\
\hline Bread + skim-milk powder & $2 \cdot 27$ & $4 \cdot 3$ & II $\cdot 5$ & $16 \cdot 4$ \\
\hline $\begin{array}{l}\text { Bread + casein } \\
\text { Standard error of the } \\
\text { mean ( } 20 \text { d.f.) }\end{array}$ & $2 \cdot 28$ & $\begin{aligned} & 4.5 \\
& \pm 0.09\end{aligned}$ & $\begin{array}{l}11 \cdot 7 \\
\pm 0 \cdot 23\end{array}$ & $16 \cdot 9$ \\
\hline
\end{tabular}

In the experiment in which bread and egg were the sources of protein the growth rate was measured over 13 days from weaning. For the experiment with milk protein, including the bread control, the period of measurement was 28 days.

\section{DISCUSSION}

Our observations illustrate the critical influence of the levels both of protein and of supplementary amino acids upon the results obtained when wheaten bread is the source of protein in the diet of young rats. This influence is also implicit in the data of Deshpande et al. (r957) who used white flour as a source of protein. With $78 \%$ of flour in the diets and a supplement of $0.25 \% \mathrm{~L}$-lysine they observed no additional effect with $0.22 \%$ DL-threonine. With a supplement of $0.5 \% \mathrm{~L}$-lysine the growth rate was no better than with $0.25 \%$ L-lysine, but when $0.4 \%$ DL-threonine was also added a further response was obtained. When only $44.2 \%$ flour was used in their diets, with a supplement of $0.3 \%$ L-lysine, there was a large additional response when $0.2 \%$ DL-threonine was added. Thus their results were broadly similar to ours. 
A more detailed analysis of these effects can be given when the level of the protein, food consumption and the level of supplementation are all considered together. It is then possible to estimate approximately the quantity of each amino acid actually ingested under different dietary conditions. Before considering this approach it is advisable to refer briefly to the question of the level of supplementation. It may be illustrated by the effects observed when increasing small quantities of L-lysine are added to bread diets of protein content about $\mathrm{x} \cdot 5^{-12.5 \%}$. The growth response increases until the supplement of lysine amounts to some $0.2-0.3 \%$, when a plateau is reached followed by a decline when more than $0.5-0.6 \%$ is added (Hutchinson et al. I $956 b$ ). It follows that an addition of $0.25-0.3 \%$ is ample to obtain optimum response, and that an addition of more than about $0.5 \%$ is undesirable, since it introduces complicating features. Now, at this protein level and with the diet supplemented with $0.25 \%$ L-lysine, there was no additional response when either threonine (Table 4 ) or additional lysine was added. Thus with these dietary conditions the lysine and threonine intakes were apparently balanced. Also at this balancing point both threonine and lysine were limiting amino acids, since there was an increase in growth rate when threonine was added together with an increased lysine supplement (0.5\%). Results given in Tables 4 and 5 illustrate these points. Thus results in Table 4 show that supplements of $0.25 \% \mathrm{~L}$-lysine and $0.1 \% \mathrm{~L}$-threonine produced no better growth than a supplement of $0.25 \%$ L-lysine without threonine whereas, as shown in Table 5, a supplement of $0.5 \%$ L-lysine and $0.1 \%$ L-threonine produced better growth than $0.25 \%$ L-lysine and $0.1 \%$ L-threonine. The results in Table 5 also show that, with a supplement of $0.5 \%$ L-lysine, a slightly better rate of growth was obtained with an addition of $0.2 \% \mathrm{~L}$-threonine than with one of $0.1 \%$. In work now proceeding we have found no further improvement in growth rate when more than $0.2 \%$ threonine (with 0.5 or $0.7 \%$ L-lysine) is added. At the first 'balancing point' (with a supplement of $0.25 \%$ L-lysine) calculation from the analytical data and from those of Table 4 shows that the mean daily intake per rat was about $53 \mathrm{mg}$ lysine and $4 \mathrm{I} \mathrm{mg}$ threonine, a ratio of $\mathrm{I} \cdot 29: \mathrm{I}$. With supplements of $0.5 \% \mathrm{~L}-1 \mathrm{ysine}$ and $0.2 \% \mathrm{~L}$-threonine the daily intake per rat was about $86 \mathrm{mg}$ lysine and $67 \mathrm{mg}$ threonine, a lysine: threonine ratio of $I \cdot 28: \mathrm{r}$, similar to that observed at the first 'balancing point'.

At lower protein levels $(7 \cdot 6-7 \cdot 8 \%$ ) (Table 4$)$ the position differed from that at the higher level $(13 \%)$ in that there was a marked response to threonine when the L-lysine addition was $0.25 \%$. However, an addition of even $0.25 \% \mathrm{~L}$-lysine is in excess of the amount required to produce the highest response possible when only this one amino acid is added. In experiments now proceeding we have found that at the protein level of $7.1 \%$ the highest response is reached with an addition of about $0.1 \%$ L-lysine. Calculation from the results obtained so far indicates that at this balancing point, for the lower protein level, the ratio of the intake of lysine to threonine is about I.3: I.

Food consumption and growth were poor at these low protein levels even when $0.25 \%$ L-lysine was added (Table 4 ). Under these conditions there might be a multiple deficiency of essential amino acids. In any event it seems that the addition of $0.25 \%$ was in excess of the amount required to balance the intake of threonine, which was 
only about $16 \mathrm{mg} / \mathrm{rat} /$ day and would account for the observed response to additional threonine.

The results obtained by those investigators who found that a supplement of lysine and threonine produced a better rate of growth than one of lysine alone, are consistent with our observations on the effect of the level of addition of such supplements in relation to the level of protein in the diet. Hundley et al. (1956) do not report the protein content of their diets which contained $93 \%$ bread-crumb and would therefore be similar in protein content to those in Table 4 . These workers used only one level of supplementation with lysine, $0.6 \%$, and found with it that a threonine supplement gave better growth than $0.6 \%$ lysine alone, an effect similar to that observed by us when the L-lysine supplement was increased to $0.5 \%$. Sure (1953) and Bender (1958) used diets of lower protein content $(\mathrm{N}=\mathrm{I} \cdot 5-1 \cdot 6 \%)$. Both Sure, with an L-lysine supplement of $0.4 \%$, and Bender, with one of $0.28 \%$, found an additional growth response when threonine was also added. As we have suggested, a supplement of $0.25 \%$ L-lysine exceeds the 'balancing' amount required at these lower protein levels, and with supplements of this magnitude a response to threonine is observed. Our results for the lower protein levels are thus consistent with those of Sure and Bender.

The predominant feature of the results with the high-protein breads (Table 2) was that lysine remained limiting even at the $24.6 \%$ protein level. With the unsupplemented diet at this protein level the daily intake per rat of lysine was only $53 \mathrm{mg}$ but that of threonine was $76 \mathrm{mg}$. A response to supplementation with lysine would therefore be expected and, as shown in Table 2, was observed when $0.4 \%$ L-lysine was added to the diet.

The comparison of growth rates on bread supplemented with lysine and threonine with those on diets with proteins from egg and milk, and on bread supplemented with these proteins (Table 6), can most usefully be discussed in terms of the actual intake of essential amino acids on the various diets. These intakes of amino acids have been calculated from the results given in Table 6 in conjunction with data on the aminoacid composition of the diets and are given in Table 7 . The amino-acid composition of the whole-egg protein was determined in these laboratories and the figures for casein were taken from Harvey (1956). Table 7 also includes for reference the quantities of essential amino acids required for optimum growth of the weanling rat calculated from the recent values of Ramarao, Metta \& Johnson (I957) which in turn were based on the earlier values of Rose et al. (1949).

The values given in Table 7 show that the relatively high rate of growth on bread, supplemented with $0.5 \% \mathrm{~L}$-lysine and $0.2 \% \mathrm{~L}$-threonine, is consistent with the improvement these additions have brought about in the balance and the amounts of essential amino acids ingested by the young rats on this diet. The intakes have been brought fairly close to those required for optimum growth, although lysine was still relatively the most deficient. The lysine intake on the bread diet supplemented with the two amino acids was a little higher than that on the bread-egg mixture, which probably explains the slightly inferior growth on the latter diet. This suggestion would seem to be confirmed by the fact that the addition of $0.2 \% \mathrm{~L}$-lysine to the bread-egg diet produced a significant improvement in the growth rate. The growth on the bread 
diets, whether supplemented with the two amino acids or with egg protein, was not as good as that on the diet with egg protein. On this latter diet, as the values given in Table 7 show, the young rats consumed more of all the essential amino acids than the amounts of each required to reach an optimum growth rate. Both growth rate and protein efficiency ratio were about the same on bread supplemented with $0.5 \% \mathrm{~L}$ lysine and $0.2 \%$ L-threonine as on the casein and bread-casein and bread-milkpowder diets. (On the milk-powder diet some rats suffered from scouring for a few days so performance on this diet is not further discussed.)

Table 7. Calculated approximate daily intakes ( $\mathrm{mg}$ ) of essential amino acids in the experiments recorded in Table 6 based on a food consumption of I I g/rat/day on diets containing $2 \cdot 2 \% \mathrm{~N}$

\begin{tabular}{|c|c|c|c|c|c|c|}
\hline \multirow[b]{2}{*}{ Amino acid } & \multicolumn{5}{|c|}{ Intake from diet containing } & \multirow[b]{2}{*}{$\begin{array}{c}\text { Optimum } \\
\text { intake }\end{array}$} \\
\hline & Egg & Casein & $\begin{array}{l}\text { Bread + } \\
0.5 \% \mathrm{~L}- \\
\text { lysine }+ \\
0.2 \% \mathrm{~L}- \\
\text { threonine* }\end{array}$ & $\begin{array}{c}\text { Bread + } \\
\text { egg }\end{array}$ & $\begin{array}{c}\text { Bread }+ \\
\text { casein }\end{array}$ & \\
\hline Lysine & 109 & 122 & $86(31)$ & 70 & 76 & 99 \\
\hline Leucine & I 35 & I 5 I & I 17 & 127 & I 34 & 77 \\
\hline Valine & 101 & I I I & 67 & 84 & 89 & 60 \\
\hline Phenylalanine + tyrosine & $86+53$ & $82+80$ & $78+52$ & $82+57$ & $80+66$ & 77 \\
\hline Methionine + cystine & $60+36$ & $49+6$ & $3 I+35$ & $45+35$ & $40+2 I$ & 55 \\
\hline Isoleucine & 88 & 96 & 59 & 73 & 77 & 60 \\
\hline Threonine & 78 & 68 & $67(45)$ & $6 r$ & 56 & 55 \\
\hline Histidine & 36 & 46 & 33 & 34 & 39 & 27 \\
\hline Tryptophan & I 6 & 15 & 16 & 16 & I5 & 16 \\
\hline
\end{tabular}

* Figures in parentheses would be the values for lysine and threonine if the bread were unsupplemented but the food intake remained constant.

$\dagger$ Values of Ramarao et al. (1957).

In general the growth rates given in Table 6 reflect the pattern of essential amino acids in the protein sources. Egg protein, with its well-balanced pattern, promoted the best growth. Casein, as is well known, has a less satisfactory balance of amino acids than egg protein because of its lower methionine content, which accounts for the rate of growth being lower than with egg protein. But, as a supplement to bread, casein was slightly better than egg protein (Table 6). This superiority was due to its relatively high content of lysine which corrects the primary deficiency of bread protein. This superiority as a supplementary source of lysine is reflected in the values of Table 7 which show that the intake of lysine from the bread-casein diet was higher than that from the bread-egg diet.

\section{SUMMARY}

I. The content of amino acids in flours of high protein content (up to $26.8 \%$ ) derived from flour of average protein content by the technique of air classification was determined by chromatography on columns of an ion-exchange resin.

2. The amino-acid composition of the protein of these flours was closely similar to that of the parent flour.

3. The rate of growth of weanling rats (seven/treatment) on diets containing bread 
prepared from these flours was measured. The protein contents of the diets were I0.8, $15.0,18.8$ and $24.6 \%$, with and without a supplement of $0.4 \%$ L-lysine. With the unsupplemented diets there was a progressive but moderate increase in growth rate as the protein level was raised. Supplementation of the diet containing $24.6 \%$ protein with $0.4 \% \mathrm{~L}$-lysine increased the growth rate by about $85 \%$. Thus growth was limited at all levels of protein by a deficient intake of lysine.

4. There was no greater response in growth rate with a supplement of $0.5 \%$ L-lysine than with one of $0.25 \%$ when the protein level $(\mathrm{r} 3 \%)$ was about that of commercial bread. When, at this level of protein, $0.1-0.2 \%$ L-threonine was added together with $0.25 \%$ L-lysine there was no improvement in growth rate over that obtained with the L-lysine supplement alone. But when L-threonine $(0 \cdot I-0.2 \%)$ was added together with $0.5 \% \mathrm{~L}$-lysine there was a further significant improvement in the growth rate.

5. At lower levels of protein $(7-8 \%)$ the results were different in that with a supplement of $0.25 \% \mathrm{~L}$-lysine there was an additional response when $0.1 \% \mathrm{~L}$-threonine was also added.

6. The growth rate and protein efficiency ratio with bread protein (13.0\%) supplemented with L-lysine $(0.5 \%)$ and L-threonine $(0.2 \%)$ were compared with those observed, at the same protein level, with casein, skim-milk powder, whole-egg protein and with mixtures of bread and casein, bread and skim-milk powder and bread and egg protein in which half the protein was supplied by bread. The performance on the bread supplemented with the two amino acids was about the same as that on casein, bread-casein and bread-milk-powder mixtures. Growth rate on the supplemented bread was about $85 \%$ of that on the whole-egg protein, and the protein efficiency ratio about $80 \%$.

7. The influence of the levels both of protein and of supplementary amino acids upon the results observed is stressed. The results are discussed in relation to the intakes of essential amino acids (calculated from data on amino-acid composition and from the observed intakes of food) with particular reference to the balance of lysine and threonine ingested at different levels of protein.

We are grateful to $\mathrm{Mr} \mathrm{E}$. E. McDermott who carried out the amino-acid analysis and to Mr G. G. Grindley for his careful supervision of the animals used in this work.

\section{REFERENCES}

Allison, J. B. (1949). Advanc. Protein Chem. 5, I 55.

Bender, A. E. (1957). Proc. Nutr. Soc. 16, xviii.

Bender, A. E. (1958). Science, r27, 874.

Deshpande, P. D., Harper, A. E. \& Elvehjem, C. A. (1957). F. Nutr. 62, 503.

Harvey, D. (1956). Tables of the Amino-acids in Foods and Feedingstuffs. Slough: Commonwealth Agricultural Bureaux.

Hoffman, W. S. \& McNeil, G. C. (r949). F. Nutr. 38, 33 I.

Hundley, J. M., Ing, R. B. \& Krauss, R. W. (1956). Science, 124, 536.

Hutchinson, J. B., Moran, T. \& Pace, J. (1956a). Proc. roy. Soc. B, 145, 270.

Hutchinson, J. B., Moran, T. \& Pace, J. (1956b). Nature, Lond., r78, 46.

Jones, C. R., Halton, P. N. \& Stevens, D. J. (1959). F. biochem. microbiol. Tech. Engng, I, 77.

Jones, J. H. \& Foster, C. (1942). F. Nutr. 24, 245.

McDermott, E. E. \& Pace, J. (1957). Brit. F. Nutr. Ix, 446. 
Moore, S. \& Stein, W. H. (195I). F. biol. Chem. 192, 663.

Osborne, T. B. \& Mendel, L. B. (1914). F. biol. Chem. 17, 325.

Ramarao, P. B., Metta, V. C. \& Johnson, B. C. (1957). Fed. Proc. 16, 397.

Rose, W. C. (1937). Science, 86, 298.

Rose, W. C., Smith, L. C., Womack, M. \& Shane, M. (1949). F. biol. Chem. r8r, 307.

Rosenberg, H. R. \& Rohdenburg, E. L. (1952). Arch. Biochem. Biophys. 37, $46 \mathrm{r}$.

Rosenberg, H. R., Rohdenburg, E. L. \& Baldini, J. T. (1954). Arch. Biochem. Biophys. 49, 263.

Sure, B. (1953). F. Nutr. 50, 235 .

Waddell, J. (1958). Processed Plant Protein Foodstuffs. New York: Academic Press Inc.

\title{
The use of Dolichos lablab and Lathyrus sativus in the making of taamiah (bean cakes) in Egypt
}

\author{
BY SABRY RIAD MORCOS AND AMAL MORGAN BOCTOR \\ Nutrition Research Unit, National Research Centre, Dokki, Cairo, Egypt \\ (Received 13 August 1958-Revised 17 November 1958)
}

In Egypt, where the consumption of animal foods is low, legumes and pulses occupy a prominent position in the national dietary. Broad beans and lentils come first in order of legume consumption.

Lately, however, home-grown lentils and broad beans have failed to meet local demand. The population is growing at an alarming rate, but the cultivable area remains about stationary.* To make matters worse the bean crop has lately been attacked periodically, on an unprecedented scale, by the vegetable parasite Orobanche crenata Forsk., known locally as halook, and also by some virus diseases. Both together adversely affect not only the yield but also the quality of the seed itself.

To understand the seriousness of the bean shortage one has to remember that broad beans (Vicia faba L.) are the basis of two most popular breakfast foods, stewed beans and bean cakes or taamiah. Crowded shops selling both articles are now found in all quarters of Cairo, though formerly their sale was restricted to poorer districts. This spreading popularity must also be contributing to the present high demand for broad beans. To relieve the shortage, the Ministry of Supply imports beans and lentils from China, Syria and Ethiopia.

Aware of the nutritional and financial situation, this Unit wished to supplement governmental effort by introducing two edible leguminous seeds that grow in the south, at present on a limited scale, in Quena and Assuan, both for human consumption and as animal fodder. The idea was to replace broad beans, either partly or completely, in some of the popular dishes by one of these two legumes and, should this measure be successful, to encourage their cultivation on a wider scale.

This is a description of an attempt to use the seeds of gueshrangaig, the Egyptian or hyacinth bean (Dolichos lablab L.) and gilban, the blue vetch (Lathyrus sativus L.) as substitutes for broad beans in the making of taamiah.

* In 1917 the population was 12795000 and cultivable land 5268528 acres, in 1957 the population was 24269500 and cultivable land 56954 II acres. 